\title{
Full Battery and Hybrid Bus based Rapid Transit System as a Cost-Effective Urban Transit Mode alternative to Metros in Tier II/ Tier III Indian Cities
}

\author{
T Dilip Kumar
}

\begin{abstract}
Intra-city travel is a significant part of urban life and a fully functional intra-city transit system will help in reducing the number of private vehicles on the road, thus reducing pollution and traffic congestions. A robust urban transit system helps in the physical expansion of city limits, making education, job, and medical facilities accessible to people living in city fringe areas. This will help in depopulating the Central Business District areas and optimization of real estate cost. Heavy Rail Based Metro Transit system has improved living conditions in Metropolitan cities. The High Capital Investment required for setting up a metro system necessitates the requirement of alternate Transit systems for Medium and smaller cities. This paper delves into this important area of suggesting an alternate urban transit model for Tier II and Tier III Indian cities. In this paper, modifications were suggested in the Metro Neo specification issued by the Ministry of Housing and Urban Affairs [10], to make it more cost-effective (to construct and maintain), agile, and with scope to harness new technologies as they become commercially viable in the future. Elevated or dedicated Busways with Full Diesel Hybrid Buses comprising an Energy Storage system (Li-ion battery pack) and a diesel power pack are suggested as the rolling stock for the transit system. This suggested rolling stock will be not only cost effective but also environmentally friendly. In the future, the Diesel Power Packs in the buses can be replaced with Hydrogen Fuel Cells or additional batteries to enable full electric and non-fossil fuel operation. The need for further research in developing cost-optimized structures in the Construction of viaducts and bus stations is felt and details in these areas have been highlighted. The suggested system will have the flexibility of a Bus Rapid Transit system and shall have some advantages of a metro system. Even in big cities with a full-fledged Metro system, the suggested modified Metro Neo system can act as a feeder system from faraway places. The paper proposes essential features of a transit system that is robust in present and is future-ready.

Keywords: Metro Neo, light rail transit, metro rolling stock, Bus Rapid Transit system, Diesel Hybrid Buses,
\end{abstract}

\section{INTRODUCTION}

A proper seamless functioning Public Transport system is the backbone of any major city. Urban rail transit (Metros) has become the ubiquitous choice of the major cities. There

Manuscript received on 24 September 2021 | Revised Manuscript received on 01 October 2021 | Manuscript Accepted on 15 November 2021 | Manuscript published on 30 November 2021.

* Correspondence Author

T Dilip Kumar*, M. Tech, IRSME, Phipps Road, Ayanavaram, Chennai (Tamil Nadu) India. E-mail: mail@dilipkumar.in

(C) The Authors. Published by Lattice Science Publication (LSP). This is an open access article under the CC-BY-NC-ND license (http://creativecommons.org/licenses/by-nc-nd/4.0/) are 13 Operational Urban Rail Transit systems (Metros) in various Indian cities comprising approx $750 \mathrm{Kms}$ of operational lines. Delhi metro with an approximate length of $350 \mathrm{kms}$ is the biggest metro network in India, catering to 900 million passengers annually. However, the cost of building a metro is high, including land acquisition and taxes - it is around Rs 200 crores per Kilometer. As per [1], the cost of Gujarat Metro is Rs 10,773 Crores for a distance of 37.766 kms. Given the high capital cost and related operational cost, alternatives to a metro system are required for Tier II/ Tier III cities. This paper delves into the alternatives to Urban Rail Transit system (metros) and suggests cost reliable system for Tier II/Tier III cities. While doing so, I also present further suggestions and modifications to the current alternative systems under pipeline. The principal purpose is to propose a system that is scalable, amenable to future technologies as and when they emerge, and quicker project execution.

\section{WHY ALTERNATIVES ARE NEEDED TO METRO TRANSIT} IN SMALLER CITIES?

Delhi Metro is an example of how a Modern Metro system can improve the living conditions of a city. We cannot comprehend the contribution of World Class Metro to the development of National Capital in simple arithmetic. However, the following issues hamper the implementation of metros in smaller cities (Tier II or Tier III cities).

\section{A. Higher Capital Cost of Metros}

The cost of a few of the metros in Indian cities-

Table- I: Cost of Metro Projects in Indian Cities

\begin{tabular}{|l|l|l|l|l|}
\hline \multirow{2}{*}{ Metro } & \multicolumn{4}{|c|}{ Table Column Head } \\
\cline { 2 - 5 } & Kms & $\begin{array}{c}\text { No. of } \\
\text { Stations }\end{array}$ & $\begin{array}{c}\text { Cost (Cr } \\
\text { Rs) }\end{array}$ & $\begin{array}{c}\text { Annual Ridership } \\
\text { (in Millions) }\end{array}$ \\
\hline Hyderabad & 72 & 57 & 18,800 & 173 \\
\hline Gujarat & $43^{*}$ & $38 *$ & 10,773 & 4 \\
\hline
\end{tabular}

+Based on [2];*Total planned

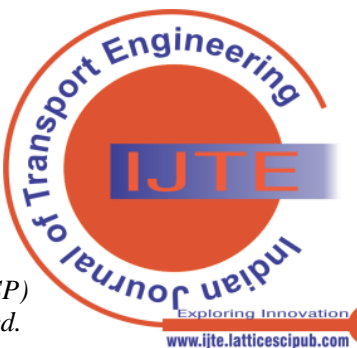



Full Battery and Hybrid Bus based Rapid Transit System as a Cost-Effective Urban Transit Mode
alternative to Metros in Tier II/ Tier III Indian Cities

Table- II: Various Options of Urban Public Transport and comparison of Parameters

\begin{tabular}{|c|c|c|c|c|c|c|}
\hline & Metro & LRT & Existing Railway & Mono Rail AGT & BRT & Bus \\
\hline $\begin{array}{l}\text { Exclusive or } \\
\text { nonexclusive } \\
\text { tracks/lanes }\end{array}$ & $\begin{array}{l}\text { Dedicated } \\
\text { tracks, grade } \\
\text { separated } \\
\text { crossings with } \\
\text { other transport } \\
\text { facilities }\end{array}$ & $\begin{array}{l}\text { Dedicated track } \\
\text { operation } \\
\text { partly with } \\
\text { mixed traffic }\end{array}$ & $\begin{array}{l}\text { Inter-city } \\
\text { transport } \\
\text { mixed with } \\
\text { commuter } \\
\text { transport }\end{array}$ & $\begin{array}{c}\text { Dedicated tracks, } \\
\text { grade-separated } \\
\text { crossings with } \\
\text { other transport } \\
\text { facilities }\end{array}$ & $\begin{array}{c}\text { Dedicated and } \\
\text { non- dedicated- lane } \\
\text { operation }\end{array}$ & $\begin{array}{l}\text { Mixed } \\
\text { traffic }\end{array}$ \\
\hline $\begin{array}{l}\text { Intervals between } \\
\text { stations }(\mathrm{km})\end{array}$ & 1.5 & 0.8- 1.5 & $3-15$ & 0.8-1.5 & 04- 1.0 & $0.2-0.4$ \\
\hline $\begin{array}{l}\text { No. of seats } \\
\text { (per unit car) }\end{array}$ & $50-80$ & $65-85$ & $60-90$ & $30-75$ & $\begin{array}{l}\text { Standard car } 40 \\
\text { Articulated } \\
\text { car 65-85 }\end{array}$ & $\begin{array}{c}\text { Standard car } \\
40 \\
\text { Articulated } \\
\text { car 65-85 }\end{array}$ \\
\hline $\begin{array}{c}\text { Average speed } \\
(\mathrm{km} / \mathrm{h})\end{array}$ & $25-55$ & $20-30$ & $40-60$ & $25-40$ & $15-35$ & $15-35$ \\
\hline $\begin{array}{l}\text { Construction } \\
\text { cost (million } \\
\text { USD/km) }\end{array}$ & $\begin{array}{c}60-100 \\
\text { (Underground) } \\
30-50 \\
\text { (Viaduct) }\end{array}$ & $30-50$ & $10-20$ & $30-50$ & $6-13$ & \\
\hline
\end{tabular}

*Source- JICA Experts Study for the Operations and Maintenance Structure of Mumbai Metro Line 3 Project in India Final Report (\#Page-12)

+ PPHPD- stands for passengers per hour per direction

Table- III: Comparison of Sub-urban Railway, Metros, and Buses of few Metropolitan cities of India

\begin{tabular}{|c|c|c|c|c|c|c|c|}
\hline \multirow{2}{*}{ City } & \multicolumn{3}{|c|}{ Sub-urban } & \multicolumn{3}{|c|}{ Metro } & \multirow{2}{*}{$\begin{array}{c}\text { Bus } \\
\begin{array}{c}\text { Ridership (in } \\
\text { Billions) }\end{array}\end{array}$} \\
\hline & Stations & $\begin{array}{l}\text { Length } \\
\text { (Kms) }\end{array}$ & $\begin{array}{l}\text { Ridership (in } \\
\text { Billions) }\end{array}$ & Stations & Length & $\begin{array}{l}\text { Ridership (in } \\
\text { Billions) }\end{array}$ & \\
\hline Mumbai & 150 & 427.50 & 2.2 & 12 & 11.4 & 0.126 & 0.912 \\
\hline Kolkata & 458 & 1,501 & 1.2 & 33 & 38.56 & 0.256 & 0.730 \\
\hline Chennai & $300+$ & 1,174 & 0.9 & 42 & 54.5 & 0.042 & 2.2 \\
\hline Hyderabad & 28 & 50 & 0.8 & 57 & 67 & 0.173 & 1.2 \\
\hline Delhi & $*$ & 85 & $*$ & 253 & 348.51 & 0.926 & 1.1 \\
\hline
\end{tabular}

*Details of Delhi sub-urban are not available

and as can be seen from Table-I, the cost of Metro is approximately Rs 200 to 250 crores per Kilometer of Length. If it is underground, the cost shoots up to approximately Rs 500 crores per $\mathrm{km}$. Such a high capital cost inhibits the introduction of Metro, where sufficient ridership is not expected. Also, the operational costs are high, as with any public transit system. The reasons for the higher cost are as follows-

1. Rolling stock with higher axle loads of $18 \mathrm{~T}$ are required to cater to the huge commuters transported. As a result, heavy structures are required to support the operations.

2. 2-3 minutes headway requires significant investment in signaling.

3. Stations are to be equipped with escalators, passages, parking spaces, lifts to cater to the huge influx of passengers.

4. For faster train operations, permanent ways (railway tracks) are required to be straighter, with less curvature and the less gradient.
5. To perform mass transit safely, urban railways shall be equipped with dedicated tracks that cross the roads and other railways through grade-separated crossings. This requires separate tracks on viaducts or tunnels.

\section{B. Longer Project execution times}

Most of the Metros take 5 to 10 years in construction. Legal issues in Land acquisition sometimes add more to the project delays and associated cost escalation.

\section{Advantages}

A Metro transit system is the most proven and safe Urban Transit system. For metropolitan cities, Metro rail is the only option. The pollution generated per person-km in the Metro transit system is less than that of any other public or private transport. As the Metro network grows and more people travel by metro, the cost per passenger-km drops significantly and operational profits are feasible. 
Table- IV: Parameters of BRT systems of various cities globally

\begin{tabular}{|c|c|c|c|c|c|c|}
\hline City & Stations & $\begin{array}{c}\text { Length } \\
\text { (Kms) }\end{array}$ & $\begin{array}{c}\text { Annual } \\
\text { Ridership (in } \\
\text { millions) }\end{array}$ & PPHPD & $\begin{array}{c}\text { Speed } \\
\text { (Kmph) }\end{array}$ & Bus Lanes \\
\hline Bogota [4] & 139 & 114 & 657 & 49,000 & 25 & Dedicated surface roads \\
\hline Guangzhou[5] & 26 & 22 & 255 & 26,900 & 21 & Dedicated surface roads \\
\hline Lima[6] & 38 & 26 & 148 & 22,800 & 25 & Dedicated surface roads \\
\hline Jakarta[7] & 244 & 251.2 & 265 & 5,000 & 20 & 1 corridor elevated, other 12 corridors \\
surface roads
\end{tabular}

As per Metro Rail Policy, 2017 [3]_"Metro rail, though being capital intensive, provides the much needed high capacity rapid transit in the cities. Though they have a life of 100 years and beyond, because of the nature of construction, the flexibility in design changes after the construction is very limited. Hence, they should be planned and executed with a longer future perspective. Being a high-capacity transport system, they are most suited for growing cities having a prospective increase in population over several years. Therefore, the metro rail systems are best suited for cities with teeming population and favorable future growth prospects."

\section{Alternatives available}

Table-II gives a comparison of various modes of Urban Transport. The alternatives to Metros in India are as follows-

1. Existing Sub-urban Train network

2. Light Rail Transport (Called Metro lite in India)

3. Bus Rapid Transit System (BRTS)

4. Metro Neo (A modified version of BRTS)

5. Monorail (More or less discarded in India)

6. Buses running on the existing road network

I gave a comparison of these modes in Table-II.

In Table- II, Transportation Capability expressed in Passengers per Hour per Direction (PPHPD) is a measure of the route capacity of a rapid transit or public transport system. Given the Technical complexity and non-standardization, Monorail projects have now taken a back seat in India. Suburban Railways can cater to the urban transit requirements effectively. But given the higher land acquisition costs and already congested cities, it is impossible for new Sub-urban rail networks. Whereas there are 8 metropolitan cities in India, there are about 83 Tier II/ Tier III cities. The Mass Rapid transit system of existing railways already exists in some of the Metropolitan cities. Table -III summarizes the ridership of various public transit systems existing in some cities.

From Table-III, we can note that:

- Cities having established Mass Rapid Transit Rail system cater to significant Annual ridership.

- Delhi Metro with a near billion Annual ridership is the metro system with the highest patronage. Delhi's sub-urban Railway is not well established like that of Mumbai and Chennai.

- Chennai, with a good Sub-urban railway network and good road network along with a city bus network, has comparatively less patronage of its Metro despite having a significant Metro Network.

- Mumbai, with the most established Sub-urban network, is way ahead in the Annual Ridership by Sub-urban trains, but its metro patronage is quite less. The low network coverage of the metro system is also one reason.

- Buses still cater to significant ridership even with Metros and Sub-urban Railway network. Buses provide the last mile connectivity to Sub-urban trains, Metros, and connectivity to areas where Metros and trains are yet to touch.

As we can see from Table -II, the Bus Rapid Transit System and Light Rail Transport (LRT) seem to be the viable options for smaller cities. The LRT system is nothing but a smaller and lighter Metro-type rolling stock or Tram-like rolling stock catering to the cities. But for LRT, the cost of setting up is just slightly less than Heavy Metro. Another viable option is the Bus Rapid Transit system.

The Ministry of Urban Development had introduced the following policy guidelines for public transport in smaller cities-

1. Metro lite - LRT system

2. Metro Neo-A modified BRT system

I gave the salient features of the Metro Neo system and the modifications suggested by me below.

\section{BUS RAPID TRANSIT}

Before going into details of Metro-Neo, this section gives the details about Bus Rapid Transit system. As per National BRT Institute, USA [4]-"Bus Rapid Transit (BRT) is an innovative, high-capacity, lower-cost public transit solution that can achieve the performance and benefits of more expensive rail modes. This integrated system uses buses or specialized vehicles on roadways or dedicated lanes to quickly and efficiently transport passengers to their destinations while offering the flexibility to meet a variety of local conditions. BRT system elements can easily be customized to community needs and incorporate state-of-the-art; low-cost technologies that attract more passengers and ultimately help reduce overall traffic congestion."

Table-IV shows the parameters of some of the largest BRT systems of the globe. As per the data, we can see that BRT systems can cater to an array of requirements. There are various successful BRT systems across the Globe. In India, BRTS was tried in various cities, but some of them failed to meet the expected outcome.

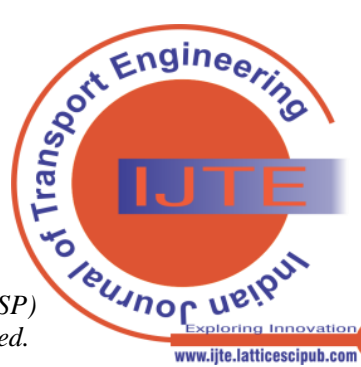




\section{Full Battery and Hybrid Bus based Rapid Transit System as a Cost-Effective Urban Transit Mode alternative to Metros in Tier II/ Tier III Indian Cities}

The main reason can be improper implementation without proper holistic study. Currently, Ahmedabad, Pune, and Indore are having functional BRT systems.

To overcome the difficulties experienced in existing BRT systems and bridging the gap between Heavy Metro transit and Bus Transit, in November 2020, MINISTRY OF HOUSING AND URBAN AFFAIRS issued [10] "STANDARD SPECIFICATIONS OF METRO NEO" for Bus based Rapid Transit system having features of LRT.

\section{METRO NEO}

Features of proposed Metro Neo System [10] -

\section{A. Civil Structure-At Grade}

- Dedicated path separating the road traffic with Metroneo lane.

- Continuous plinth /fencing/kerb for segregation from other road traffic.

- $\quad$ The Right-of-Way (RoW) - 8.0 meters for both UP \& DN lane combined.

- Guidance system.

- Platform width - 1.12 m (side), 4m(island)

B. Civil Structure - Elevated

- Road space occupied - Maximum 2.2 m at median for piers including crash barrier.

- Edge to edge width of the viaduct - 8-meter maximum.

- Vertical clearance $-5.5 \mathrm{~m}$

- Platform width - 1.12 m (side), 4m(island)

- Pedestrian crossing - traffic calming measures \& signage/signal

- Access to the station - Staircase and Elevators for People with Restricted Mobility (PRM) and old.

\section{Rolling stock}

The Rolling stock comprises rubber-tyred buses running on road slabs.

- Length-12 m (Single coach)

- 18-meter length (two articulated coaches)

- 24 meter (three articulated coaches)

- Width - 2.55m

- Axle load-10 T

- Floor height-300-350 mm

- Kerb Rail/Centre Rail guidance

- Electrical Hybrid coach - running on OVERHEAD EQUIPMENT (OHE) with onboard battery

- Onboard battery - which can support a range of 20 $\mathrm{Km}$

- Coupler at both ends for coupling in case of any failure

\section{Traction and Power Supply system}

- Traction system - 750 V DC OVERHEAD EQUIPMENT (OHE)

- Twin, positive, and negative contact wires in parallel

- Traction Sub Station (TSS) - from city's electric power supply authority at HT voltage level (11/22/33 $\mathrm{kV} / \mathrm{as}$ available)

- Supervisory Control and Data Acquisition (SCADA) for OVERHEAD EQUIPMENT (OHE) monitoring

\section{E. Other Features}

Table- V: Specification of Metro Neo System

\begin{tabular}{|l|l|}
\hline Feature & Specification \\
\hline Rail Guidance & Kerb Rail Guidance/Centre Rail Guidance \\
\hline Signaling System & $\begin{array}{l}\text { Automatic Train Protection (ATP) system with } \\
\text { anti-collision feature and pre-defined speed limit } \\
\text { and operation shall be monitored by central } \\
\text { control }\end{array}$ \\
\hline Telecom & $\begin{array}{l}\text { Radio-based communication between driver and } \\
\text { control room. Fiber-optic based communication } \\
\text { system for CCTV surveillance, Public } \\
\text { Information, Data Communication, Master } \\
\text { Clock. }\end{array}$ \\
\hline $\begin{array}{l}\text { Automatic Fare } \\
\text { Collection (AFC) }\end{array}$ & $\begin{array}{l}\text { The ticketing system shall be based on National } \\
\text { Ticket Vending Machine (TVM), Add Value } \\
\text { Machine (AVM), etc. shall be provided at the } \\
\text { stations }\end{array}$ \\
\hline $\begin{array}{l}\text { Maintenance } \\
\text { Control Operation } \\
\text { (OCC) Centre }\end{array}$ & $\begin{array}{l}\text { Maintenance and stabling or more facilities for } \\
\text { coaches can be done in one depot } \\
\text { OCC shall be simple with bare minimum facilities }\end{array}$ \\
\hline Security & CCTV surveillance system \\
\hline
\end{tabular}

\section{SUGGESTED}

IMPROVEMENTS/MODIFICATIONS

The Metro Neo is a bridge between Light Rail Transit (LRT) and a Bus Rapid Transit System (BRT). Metro Neo is a good viable option for Tier II and Tier III cities. The cost of the Metro Neo section will be around Rs.71 cores per Km compared to Rs 222 Crore per Km for a regular metro and Rs 140 crores for a Light Rail Transit. I gave the cost comparison between Metro Neo and Regular Heavy Metro in Table VI.

I am suggesting the following modifications in the Metro Neo system for cost reduction and flexibility-

- A system without Overhead Equipment (OHE) and associated traction substations. This will reduce the capital cost and also operational cost. In some cities, it may require additional expenditure to improve the traction supply. OHE also adds to the cluster and increases the cost of civil infrastructure.

- Without using OHE, the options leftover are-Full Diesel Buses/coaches, Battery-powered buses with charging infrastructure at depots and junctions.

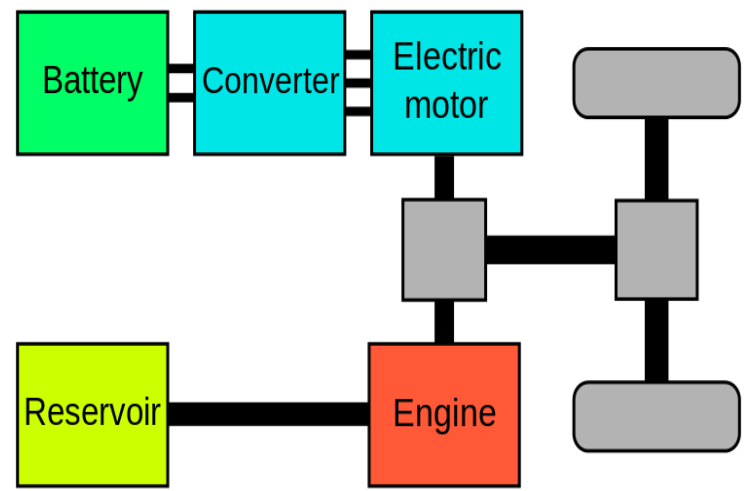

Fig. 1. Parallel Hybrid Drive Mechanism

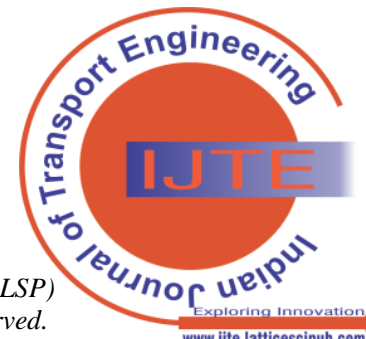




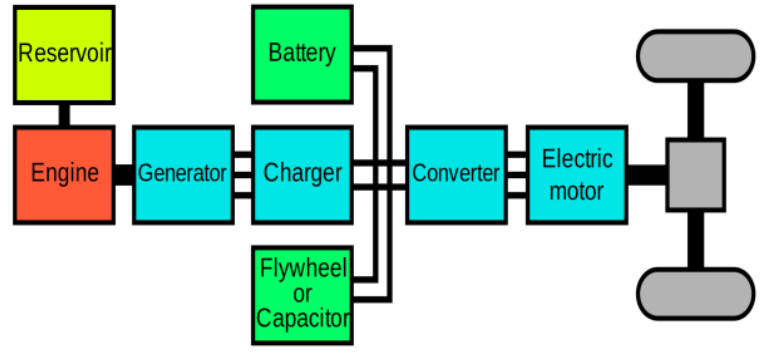

Fig. 2. Series Hybrid Drive Mechanism

- Currently, all major BRT systems use Diesel Buses. But various countries are changing over to Electric Buses.

Eg- Jakarta BRT is switching over to electric buses. Kuala Lumpur BRT uses Electric buses.

- Even electric buses require charging infrastructure. The time required for charging is also significant.

- So keeping the best of both, i.e. flexibility of Diesel Buses and environmental friendliness of Electric Buses, Hybrid Coaches using Diesel Engine and Onboard Energy Storage system (Battery) are suggested. Such buses are already being used in cities of China and New York [18].

- Further, I discussed details about the suggested rolling stock below.

\section{A. Diesel Battery Hybrid Buses}

I am suggesting using 12 meters and 18 meters (articulated) Diesel Series Hybrid Buses with a Plug-in facility (for charging) for the Metro Neo transit system. The Buses will be having a Kerb guidance mechanism. Diesel Hybrid buses are already being used in some of the BRT systems like Mexico BRT, BRTs of various cities of China like Guangzhou, Changzhou, etc. [11]

I discuss details of Hybrid Drive below.

\section{B. Suggested Hybrid Drive of the Rolling stock}

- There are two types of Hybrid drive systems-Parallel Hybrid and Series Hybrid.

- The parallel hybrid drive is illustrated in Fig.1. In this system, the diesel engine is mechanically connected to the driving wheels like conventional buses. The electric motor is also coupled with the driving wheels. In this system, the engine, the Electric motor, or any of the two can drive the vehicle. They employ smaller battery and their range of electrical power is limited.

- Series hybrid is illustrated in Fig.2. In this system, the diesel engine is not mechanically connected to the driving wheels. The Diesel engine charges the Energy Storage system (Battery).

- From energy storage (Battery) onwards, the bus is like an Electric bus.

- The engine is mechanically disconnected from the drive wheels and the Diesel engine can operate at its optimum rpm, improving efficiency. The battery acts as an energy buffer which will be charged by the Diesel engine and through regenerative braking.

- The battery in a Series Hybrid is of higher capacity depending on the range required. The Diesel Engine used will be smaller than that of a Conventional or Parallel Hybrid Bus.

- Parallel Hybrid buses are more efficient in Long Distance cruising travel whereas Series Hybrid Buses will be more efficient in the Start / Stop type of scenario. Examples-

- Series Hybrid- BAE ER Series [13] and Tata Start Series Hybrid Bus [14]. Fig.3. shows the illustrations of the BAE systems series hybrid.

○ Parallel Hybrid - Volvo S Charge with 240 HP Diesel Engine and $110 \mathrm{KW}$ electric motor [15]

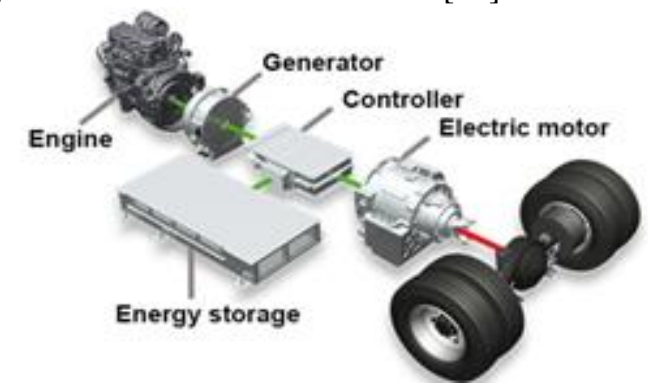

Fig. 3. Series Hybrid Drive Mechanism of BAE [16]

\section{Why Hybrid in place of Full Electric?}

I am suggesting Series Hybrid with Plug-in capability rolling stock (as shown in Fig.4.) instead of Full Electric Buses running on OHE or battery, because of the following expected advantages -

- Hybrid Vehicles don't require fully fledged charging infrastructure. However, emergency charging infrastructure is required.

- OHE and associated Traction Sub Station (TSS) are not required.

- The Diesel Hybrid can be converted to Hydrogen Buses once Fuel Cell technology gets matured.

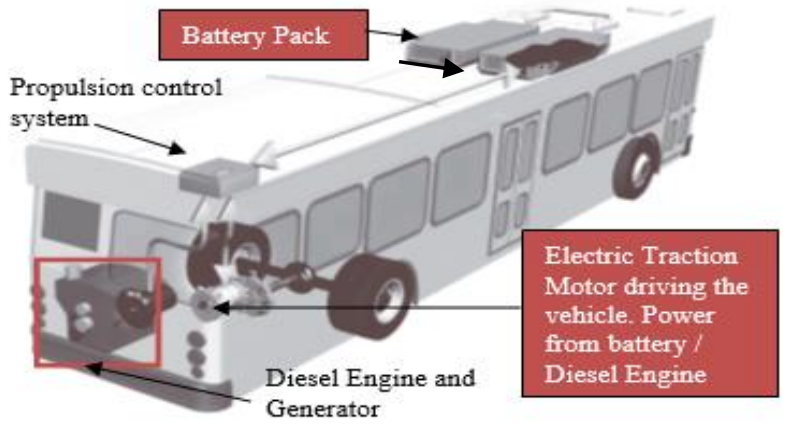

Fig. 4. Illustration of typical Series Hybrid Bus [17]

- Hybrid Rolling stock will have the flexibility of conventional diesel buses and significant reduction of emissions and fuel consumption.

- As the Hybrid has a plug-in facility, they can be charged once the charging infrastructure is fully set up. At this stage, diesel engines can be removed and additional batteries can be incorporated for an extended range.

- Battery swap technology can be implemented.

- The idea is to avoid OHE and Traction sub-station infrastructure which will seriously affect capital cost and also Maximum Moving Dimensions.

- Double-deck buses can also be used in the same Metro Neo system, which wouldn't have been possible with OHE.

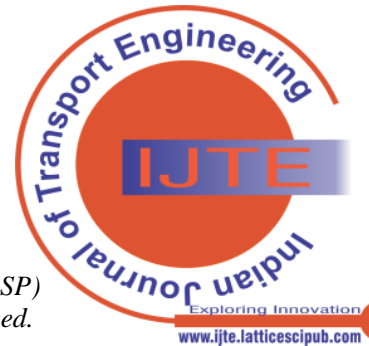




\section{Full Battery and Hybrid Bus based Rapid Transit System as a Cost-Effective Urban Transit Mode alternative to Metros in Tier II/ Tier III Indian Cities}

- Fewer maintenance skills and operating costs are expected. As Indian cities are already using Electric Buses and Hybrid buses, there will be no requirement for an additional skill set. However, the addition of OHE will necessitate the requirement of a new set of skills and associated maintenance costs.

- As the suggested vehicles can run in the Non-OHE area, these vehicles can be used in non-Metro Neo areas with no modification. This gives major flexibility, like using vehicles in other networks when there is no demand. Also, regular Diesel buses can be used as feeder buses for the main network. In case of exigencies, regular buses can ply on the Proposed Metro Neo Network.

- Autonomous driving is suggested as an additional feature for these buses for the future. Automated Bus Rapid Transit (ABRT), which is incorporating autonomous driving technology in the BRT system, is being experimented with by some of the city transport agencies. This technology can be a game-changer for bus rapid transit (BRT) lines. ABRT systems are already being tested in 14 different pilot programs across the U.S.[21].

- Once the transit system is in place and charging infrastructure is set up, Full Electric buses can be used.

My suggestion is to develop a Transit system on the same lines as Metro Neo but using Diesel Hybrid or Full Electric buses instead of using OHE. This system can be useful in Tier II and Tier III cities.

Table- VI: Cost aspects of Modified Metro Neo (my suggestion), Metro neo (Nashik DPR @ 2019 level) compared to Nagpur Metro actual costs

\begin{tabular}{|c|c|c|c|c|c|}
\hline SN & Sub-system & Description & $\begin{array}{c}\text { Suggested Modified Metro } \\
\text { Neo (Rs.Cr/KM) } \\
\text { (Col A) }\end{array}$ & $\begin{array}{c}\text { Metro neo } \\
\text { (Rs.Cr/KM) (Col B) }\end{array}$ & $\begin{array}{c}\text { Heavy Metro } \\
\text { (Rs.Cr/KM) (Col C) }\end{array}$ \\
\hline 1. & Viaduct & Smaller viaduct & $28^{+}$ & 31.5 & 36 \\
\hline 2. & Stations & $\begin{array}{l}\text { Concourse eliminated, } \\
\text { platforms height is reduced }\end{array}$ & $4^{+}$ & 4.4 & 55 \\
\hline 3. & Track & No track & 0 & 0 & 9 \\
\hline 4. & Traction \& PSI & No traction in modified system & $1^{*}$ & 4.5 & 11 \\
\hline 5. & Rolling stock & Tyred Electric coaches & 7.5 & 7.5 & 26 \\
\hline 6. & Signalling & $\begin{array}{l}\text { ATP signaling with anti } \\
\text { collision }\end{array}$ & 0.5 & 0.5 & 10 \\
\hline 7. & Depot & Less depot area & 2 & 2 & 5.5 \\
\hline 8. & Misc. Utilities & & 1 & 1 & 4 \\
\hline 9. & $\begin{array}{l}\text { Telecom \& } \\
\text { Security }\end{array}$ & $\begin{array}{l}\text { Smaller stations with optimal } \\
\text { telecom services }\end{array}$ & 1.5 & 1.5 & 5 \\
\hline 10. & $\begin{array}{l}\text { Ticket vending } \\
\text { (AFC) }\end{array}$ & No AFC gates & 0.5 & 0.5 & 3 \\
\hline \multicolumn{3}{|c|}{ Taxes, Contingencies, design charges, etc., } & 18.5 & 18.5 & 57.5 \\
\hline & & Total & 64.5 & 71.9 & 222 \\
\hline
\end{tabular}

Source: Page- 5 of [19] 


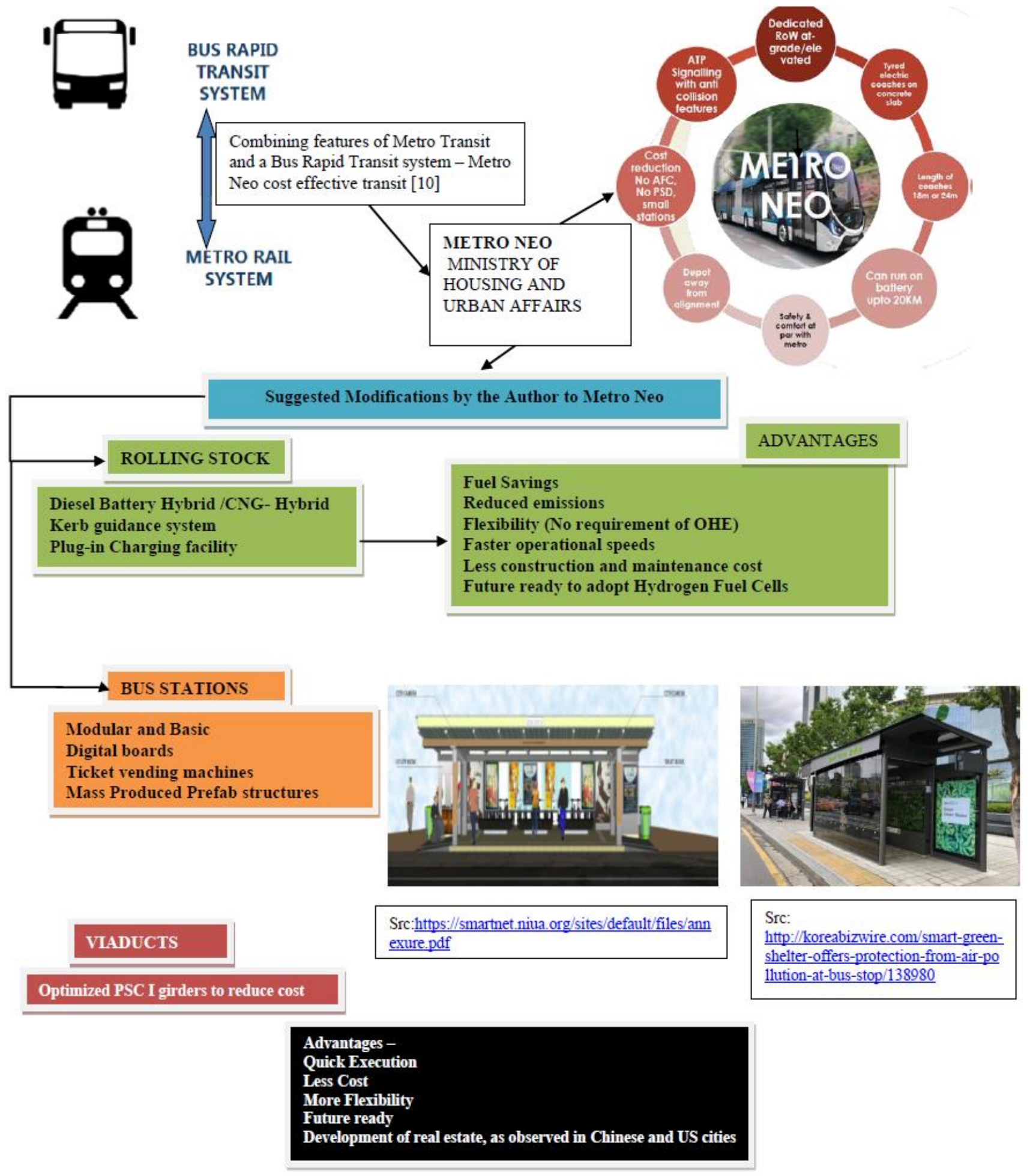

Fig. 5. Block Diagram - Explaining The Suggestions of This Paper In Brief

\section{How the proposed system differs from BRT?}

The proposed system is a toned-down version of the Metro Neo system with more similarities to the BRT system. But the proposed system is having additional features compared to a traditional BRT for enabling quick and efficient transport -

- iaducts metro Neo and the proposed system use the Kerb guidance system. This will improve the average speed of the Buses/coaches in the dedicated path.

- Small guide wheels attached to the vehicle shall engage vertical kerbs on either side of the dedicated path. These guide wheels push the steering mechanism of the vehicle, keeping it centralized on the path. Away from the guideway, the bus is steered in the normal way.

- Provision for Autonomous driving technology is suggested in the proposed system. This will improve the speed of the transit system and reduces operating costs.

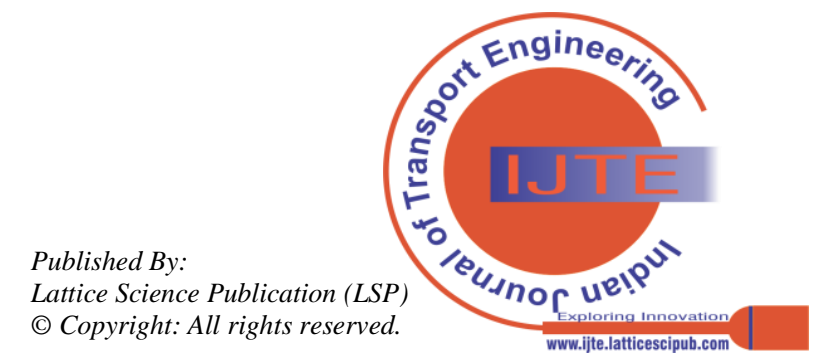




\section{Full Battery and Hybrid Bus based Rapid Transit System as a Cost-Effective Urban Transit Mode alternative to Metros in Tier II/ Tier III Indian Cities}

- By using Autonomous driving technology, more number of smaller buses can be used instead of a lesser number of longer buses. This will help in the proper utilization of assets and cost reduction. Also, headways can be reduced.

\section{CIVIL INFRASTRUCTURE}

\section{A. VIADUCTS}

The main contributing factor for the cost is the construction of Viaducts for the elevated roads. Viaducts can be avoided where enough wide roads are available in the city in which the dedicated bus bays can be aligned to the median. But where roads are heavily congested and narrow, separate elevated roads are suggested. BRT system of Delhi was established for the Common Wealth Games. But because of congestion on roads, the separate lanes were discarded [21]. Hence, for a successful implementation, elevated corridor is suggested where roads are narrow and congested. A simple PSC I girder based elevated corridor is suggested [22] in Fig.6. As elevated roadways make up a major cost component, it is suggested to carry the optimal design of I girder similar to that suggested in [23]. Such cost optimization of design will help in reducing the overall cost of the transit system. Further research in this area is essential for developing a cost-effective solution, as many Indian cities are at the edge of rapid growth, which will ultimately result in the construction of flyovers.

\section{B. Bus Stations/Stops/Halts}

The second major cost component of the transit system after viaducts is the construction of Bus stations. As the proposed transit system is more of open architecture. Improved Basic Bus stations shall be provided with basic amenities like Digital displays, Automatic Ticket vending systems, Vendor kiosks, Cycle stands, Toilets, ATMs, basic illumination, an Air circulation system, etc. The Bus stations shall be developed to be modular, so that required modules can be added where longer bus stations are required.

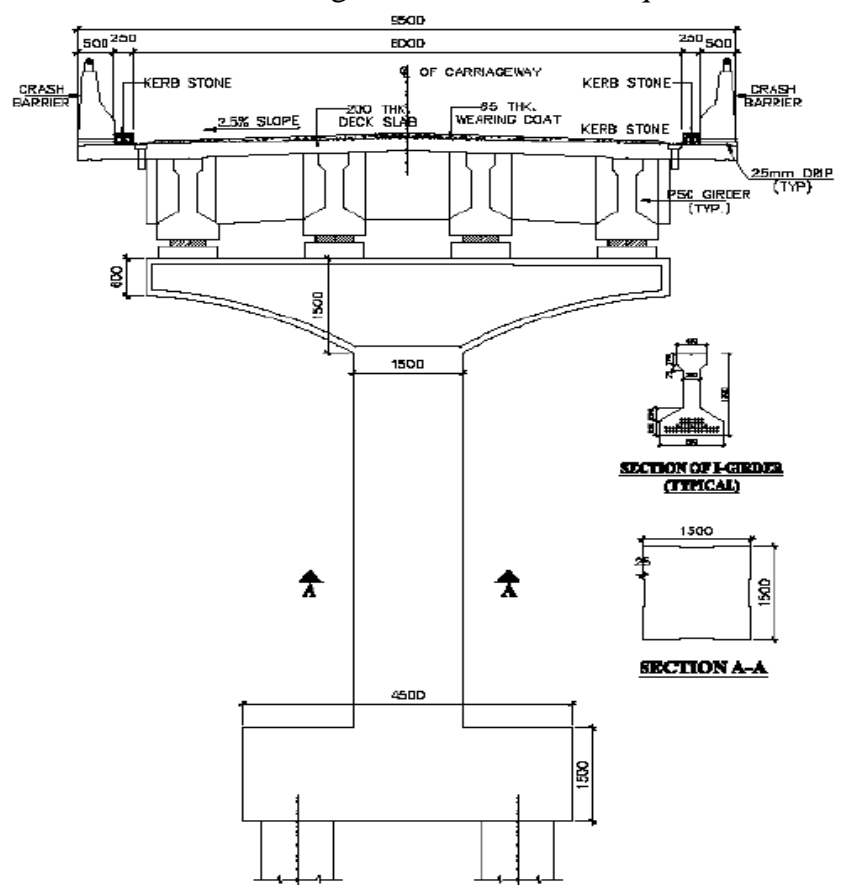

Fig. 6. Proposed design of I-girder [22]
This will help in standardization and cost optimization. Modular vending kiosks shall be made a part of the important bus stations. The stations will have bicycle stands on the grade level for last mile connectivity.

\section{RESULTS}

I represented the block diagram of the suggestions of this paper in Fig-5. The basic purpose of this paper is to suggest a cost-effective alternative to Metros for Urban transit in Tier II and Tier III cities. Capital cost comparisons between the Metro system, Metro Neo System, and the modified system suggested by me are given in Table - VI. The Table-VI is based on page 5 of [19]. Metro Neo is cheaper than a Heavy Metro system. Col (A) of Table-VI gives the details of the Modified Metro Neo System suggested in this paper. Cost reductions are explained below-

- As there will be no requirement for OHE masts, it is expected that the cost will be lower by $10 \%$. The cost reduction can be achieved by optimized design of viaduct elements like I girder as suggested in [23]. Wherever existing roads are wider, the median portion of the roads can be used as dedicated bus transit paths. This will further reduce the cost. A combination of Viaduct Busways for the places where existing roads are cramped and at-grade segregation where roads are wider can save the cost. Such detailed planning shall be carried out during the project pre-planning stage.

- $10 \%$ reduction in the cost of Station buildings is expected because of the non-availability of OHE and by using pre-fabricated simple structures. Few samples of stations are shown in Fig.5.

- Complete Traction installation cost can be eliminated, however, Rs 1 Crore per km has been added to consider for any charging infrastructure.

- Rolling stock cost is considered the same as that of Metro Neo. The cost can further reduce as Indian Bus Manufacturers can manufacture the proposed Hybrid Rolling structure. As per [14], Tata Motors had successfully manufactured and delivered Air-conditioned 12 meter Diesel Series Hybrid Buses for Mumbai.

\section{CONCLUSION}

As cities grow and the population increases, a robust, environmentally friendly, and cost-effective transit system is essential. The proposed system based on Metro Neo System will bridge the gap between traditional buses and the Heavy Metro system. The proposed technology of Series Hybrid Drive Buses is readily available for quicker implementation. The rolling stock shall be designed to harness the technologies nearing commercialization like Fuel Cells. Trials shall be carried out with Autonomous driving which can improve the transit system's efficiency and reduce the cost. Not all cities are alike - the topography, the climatic conditions, the socio-economic conditions, the aspirations of the citizens, etc. will be different. Hence one transit system cannot fit all cities.

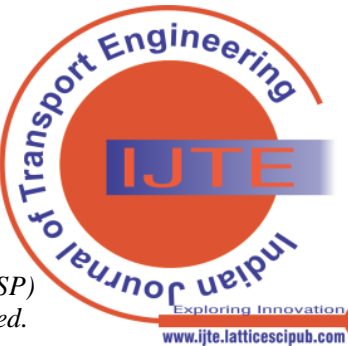


A thorough pre-planning before implementing a transit system is very much essential for a successful model. The Government of India had done a great job of introducing new transit alternatives to Heavy Metro, like Metrolite (LRT) and Metro-Neo. I feel that the suggested modifications/improvements in this paper will help in giving more options to the city planners.

\section{REFERENCES}

1. Gujarat Metro Rail Corporation (GMRC) Limited (2016). Title. Project Funding. Available:

https://www.gujaratmetrorail.com/project/project-updates/funding/

2. Wikipedia article on Hyderabad Metro https://en.wikipedia.org/wiki/Hyderabad_Metro

3. Ministry of Housing and Urban Affairs - Metro Rail Policy, 2017. Available :

http://www.mohua.gov.in/upload/whatsnew/59a3f7f130eecMetro Rail Policy 2017.pdf

4. Global BRT data- Colombia, Bogotá, https://brtdata.org/location/latin america/colombia/bogota

5. Guangzhou bus rapid transit system | China. Available https://unfccc.int/climate-action/momentum-for-change/urban-poor/gua ngzhou-bus-rapid-transit-system

6. Global BRT data- Colombia, Bogotá, https://brtdata.org/location/latin america/peru/lima

7. Wikipedia TransJakarta Available: https://en.wikipedia.org/wiki/TransJakarta

8. Global BRT Data - Istanbul Available: https://brtdata.org/location/europe/turkey/istanbul

9. Global BRT Data - Brisbane Available: https://brtdata.org/location/oceania/australia/brisbane

10. STANDARD SPECIFICATIONS OF METRO NEO November 2020 GOVERNMENT OF INDIA, MINISTRY OF HOUSING, AND URBAN AFFAIRS. Available:

http://mohua.gov.in/upload/whatsnew/5fa52ec5702e2Standard+specifi cations + of + Metro+Neo-2\%20(1).pdf

11. Institute of Transportation and Development Policy (ITDP), BRT Fuels Available: http://www.itdp-china.org/brt/quan/?quan id=33\&lang=1\&isnumber=0

12. By Fred the Oysteri - The source code of this SVG is valid. This vector image was created with Adobe Illustrator., CC BY-SA 4.0, https://commons. wikimedia.org/w/index.php?curid=36225265

13. Get Zero Brochure of BAE systems. Available: https://gettozero.com/pdf/bus/GETTOZERO BROCHURE.pdf

14. Handing over of Tata Motors Series Hybrid Buses. Available: https://www.buses.tatamotors.com/news/maharashtra-chief-minister-sh ri-devendra-fadnavis-formally-hands-over-25-tata-starbus-hybrid-electr ic-bus-from-tata-motors-to-mmrda/

15. Data Sheet of Volvo S Charge. Available:

https://www.volvobuses.com/content/dam/volvo-buses/markets/master/ city-and-intercity/chassis/volvo-b5l-s-charge/Data_sheet_B5L_S-Char ge Euro_6_2021_EN.pdf

16. Series -ER: Electric-range hybrid (BAE systems). Available: https://gettozero.com/series-er.php

17. National Renewable Energy Laboratory (NREL), US Department of Energy. Available: https://www.nrel.gov/docs/fv01osti/30736.pdf

18. Hybrid buses in New York, BAE Systems selected. It'll provide 435 systems

https://www.sustainable-bus.com/hybrid-bus/hybrid-buses-in-new-york -bae-systems-selected-itll-provide-435-systems/

19. Why Metro Neo? Ministry of Housing and Urban Affairs, Government of India. http://mohua.gov.in/upload/uploadfiles/files/Metro\%20Neo\%20System .pdf

20. CTDOT, Partners to Test Autonomous Buses on BRT Service by Alex Roman, METRO Magazine

https://www.metro-magazine.com/10124332/ctdot-partners-to-test-auto nomous-buses-on-brt-service

21. The Hindu, BRT Gets Demolished Date: December 28, 2016 https://www.thehindu.com/news/cities/Delhi/BRT-gets-demolished/arti cle16951562.ece

22. Cooperation for urban mobility in the developing world- LIGHT METRO IN URBAN TRANSPORT SECTOR (MODE CHOICE) - By S. D. Sharma, Director (Business Development), DMRC, 6th November 2017. Available:
http://www.codatu.org/wp-content/uploads/Light-metro-in-urban-trans port.pdf

23. R. Ahsan, S. Rana and S. N. Ghani (Published 2012) "Cost Optimum Design of Post-tensioned I-Girder Bridge Using Global Optimization Algorithm". Journal of Structural Engineering-ASCE. Available: https://www.optimumsystemsdesigners.com/wp-content/uploads/2014/ 04/Bridge-Design-Optimization-1.pdf [CrossRef]

\section{AUTHORS PROFILE}

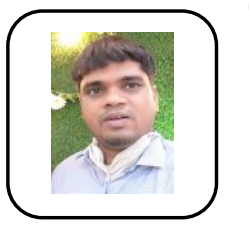

T. Dilip Kumar, BE (Mechanical), Indian Railway Service of Mechanical Engineers (IRSME-2005). was part of Mechanical Design team of New Rolling stock for Indian Railways like Kolkata Metro, Mumbai Sub-urban, and Vandebharat (Train-18). The suggestions/ideas presented here are purely personal other statutory bodies. 